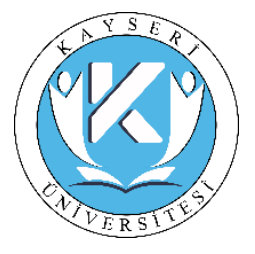

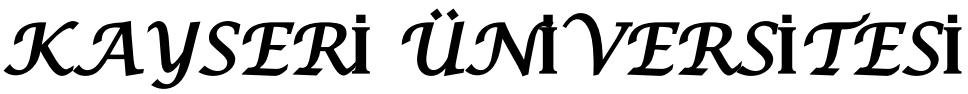 Sosyal Bilimler Dergísi

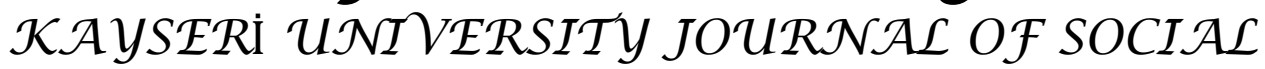 SCIENCES
}

\begin{tabular}{|l|l|l|l|l|l|}
\hline Makale Türü & Araştırma makalesi & Y1l & $\mathbf{2 0 2 1}$ & ss. & $\mathbf{1 0 - 2 3}$ \\
\hline Gönderi Tarihi & $\mathbf{2 2 . 0 4 . 2 0 2 1}$ & Cilt & $\mathbf{3}$ & DOI & $\mathbf{1 0 . 5 1 1 7 7 / k a y u s o s d e r . 9 2 6 1 6 7}$ \\
\hline Kabul Tarihi & $\mathbf{1 7 . 0 6 . 2 0 2 1}$ & Say1 & $\mathbf{1}$ & & \\
\hline Online Yayın Tarihi & $\mathbf{3 0 . 0 6 . 2 0 2 1}$ & Ay & Haziran & & \\
\cline { 1 - 3 } & & & & & \\
\hline
\end{tabular}

\section{Türk-İslam sentezcilerinde devlet tasavvuru ve din-devlet ilişkileri*u}

\section{Concept of state and religion-state relations according to Turkish-Islamic synthesizers} (1) Ahmet Selim KADIOĞLU ${ }^{1}$

Öz

Osmanlı Devleti'nin son zamanlarına kadar mevcudiyetini kendiliğinden ve neredeyse mensuplarından habersizce sürdürmekte olan bir olgu olarak değerlendirilen Türk-İslam Sentezi, 19. yüzyılın sonlarında devletin beka sorunu çerçevesinde bilinçli bir kimlik seçimi ve vurgusu olarak ortaya çıkmaya başlamıştır. O zamandan beri Türk fikir ve siyaseti üzerinde etkisini gösteren Türk-İslam Sentezcileri, doğrudan veya dolaylı biçimde devlet yönetiminde az ya da çok yer almaya devam etmişlerdir. Günümüzde ise "Cumhur İttifakı”, Türk-İslam Sentezinin özgün bir örneği olarak devleti fiilen yönetmektedir. Devlet politikalarını, din-devlet ilişkilerini, hukuk üretimi ve uygulamalarını kurumsal birikim ve hatta teamüllerden ziyade devleti yönetenlerin kişisel tercihlerinin belirlediği Türkiye ve benzeri "doğu” toplumlarında, devlet idarecilerinin bu konulardaki genel kabullerinin ve görüşlerinin kökenlerini incelemek ve araştırmak bundan dolayı büyük önem taşımaktadır. Türk-İslam Sentezcileri, devlet olgusunu, insanlar için sosyolojik ve hukuki açıdan gerekli olan bir kurumdan daha çok, kutsal bir varlık olarak değerlendirdikleri için, sözünü ettiğimiz inceleme ve araştırma Türkiye özelinde daha üst bir düzeyde öneme sahiptir. İşte bu çalışmada Türk-İslam Sentezinin belki de en merkezi kavramlarından biri olan devlet olgusu, dinsel açıdan ve özellikle Türk-İslam Sentezcilerinin dine bakışları doğrultusunda incelenmiştir.

Anahtar Kelimeler: Türk-İslam Sentezi, Devlet, Cumhur İttifakı, Din ve Devlet İlişkisi, İslam ve Demokrasi.

\begin{abstract}
Turkish-Islamic Synthesis, considered as a phenomenon that existed by itself and almost without the knowledge of its intellectuals and supporters until the last days of the Ottoman Empire, has started to emerge as a conscious emphasis and choice of identity when faced with the issue of the State's existence. Turkish-Islamic Synthesizers, who had an influence on Turkish intellectual life and politics ever since, have continued to take part in state governance directly or indirectly, at times with more influence, and at others less. Today, "People's Alliance", as a genuine example of the Turkish-Islamic synthesis, governs the State. In Turkey and alike "eastern" societies, where policies, Religion-State Relations, law making and implementation are determined, neither through institutional knowledge, nor even customs, but through personal preferences of those who govern the State; it is important to research and study the origins of the presuppositions and personal choices of the State's governors. Since Turkish-Islamic Synthesizers view the reality of the State, as a sacred entity, rather than an institution necessary for social and legal purposes; such a study has a higher-level importance especially with regards to Turkish example. In this study, reality of the state, perhaps the most central concept of the TurkishIslamic Synthesis, is examined in reference to religion, and with a special focus to the perception of religion of the Turkish-Islamic Synthesizers.
\end{abstract}

Keywords: Turkish-Islamic Synthesis, State, People Alliance, Religion-State Relations, Islam and Democracy.

\footnotetext{
${ }^{\Delta}$ Yazarlar bu çalışmanın tüm süreçlerinin araştırma ve yayın etiğine uygun olduğunu, etik kurallara ve bilimsel atıf gösterme ilkelerine uyduğunu beyan etmiştir. Aksi bir durumda Kayseri Üniversitesi KAYÜSOSDER Dergisi sorumlu değildir.

* Bu makale doktora tezinden üretilmiştir. Makale, 2020 yılı öncesi doktora tez çalışmasında kullanılan verilerden üretilmiş olması sebebiyle etik kurul izni gerektirmeyen çalışmalar arasında yer almaktadır.

${ }^{1}$ Dr. Öğr. Üyesi, Ankara Sosyal Bilimler Üniversitesi, Hukuk Fakültesi, ahmetselim.kadioglu@ asbu.edu.tr
} 
Kadioğlu, A. S. (2021). Türk-islam sentezcilerinde devlet tasavvuru ve din-devlet ilişkilerí.

\section{Giriş}

Türk-İslam Sentezcilerinin devlet tasavvurları ve din-devlet ilişkilerine dair görüşlerinin ele alındığı bu çalışmada Türk-İslam Sentezi’nin ne olduğuna ve Türk-İslam Sentezcilerinin kimler olduğuna dair tartışmaya girilmeyecektir. Söz konusu tartışmaya Türk-İslam Sentezi'nin Oluşum ve Gelişim Süreci (Kadığlu, 2020) adlı makalemizde ayrıntılı olarak girmiştik. Dolayısıyla araştırma konumuz, Türk-İslam Sentezcilerinin devlet tasavvurları ve din-devlet ilişkilerine ilişkin görüşleriyle sınırlandırılmıştır.

Bu sınırlılık doğrultusunda burada, tarihsel açıdan Türklerde eski çağlardan itibaren devletin bir olgu ve kurum olarak anlam ve önemine, hem İslam hem de Türk tarihi bağlamında İslam ve Demokrasi arasındaki ilişkiye, Halifelik müessesesinin işlevsel ve yapısal özelliklerine, din ve bilhassa İslamiyet ile devlet arasındaki ilişkilerin mahiyetine, teokratik devlet anlayışına ve laikliğe dair Türk-İslam Sentezcilerinin görüşlerini olgusal bir tespit kapsamında olmak üzere ortaya koymaya çalıştık.

$\mathrm{Bu}$ çerçevede temel hipotezlerimizi şöyle sıralayabiliriz: Türk-İslam Sentezcilerine göre; Türklerde devlet özü itibariyle kutsal bir hüviyete sahiptir; demokrasinin temel ilkeleri nüve olarak İslam dininde yer almakta olup İslam'ın ilk dönemlerindeki ve bilhassa Müslüman Türk devletlerindeki uygulamalar bu vakıayı ortaya koymaktadır; halifelik temelde dini değil dünyevi bir müessese olup halifeler de aslen dünyevi liderlerdir; din ve devlet arasındaki sorunlu ilişki tarzı özellikle Batı ülkelerine mahsus olup, İslam ve Türk devlet geleneğinde din-devlet ilişkileri uyumlu ve birbirlerini destekler nitelikte var olagelmiştir; teokratik devlet, İslam dinine temelde zıttır ve İslami devlet anlayışı teokratik olarak nitelendirilemez; laiklik aslında din karşıtlığı anlamına gelmemekte olup öz itibariyle İslam'da mevcuttur. Dolayısıyla çalışmamızın temel amacını da, Türk-İslam Sentezcilerinin bu iddiaları ileri sürdüklerini ortaya koymak olarak özetleyebiliriz.

Diğer yandan, yukarıda her ne kadar Türk-İslam Sentezi'nin ne olduğuna ve Türk-İslam Sentezcilerinin kimler olduğuna dair tartışmaya girmeyeceğimizi ifade etmiş olsak da, çalışmamızın konusunu ve sınırlarını belirleme bağlamında Türk-İ̀slam Sentezcilerinden kimleri kastettiğimizi belirtmek gerekmektedir.

Türk-İslam Sentezi en geniş açıdan, İslamlık ile beraber Türklüğü de kimliğin vazgeçilmez, hatta kimi zaman daha önce çıkan unsuru olarak kabul eden anlayış şeklinde tanımlanabilir. Buradan hareket edildiğinde Osmanlı'nın son dönemlerinden itibaren Türk düşünce ve siyaset hayatında Türkçü, İslamcı, Mukaddesatçı, Milliyetçi, Muhafazakâr gibi adlandırmalarla anılan fikir ve siyaset adamları, milli kimliğin bu iki unsuruna aynı veya birbirine yakın önem vermeleri ölçüsünde Türk-İ̀lam Sentezcisi sayılabilirler. Bu itibarla Türkiye siyasetinin son yarım yüzyıllık periyodunda kendini göstermiş olan Milliyetçi Cephe (MC) hükümetleri, Özal hükümetleri ve nihayet günümüzde Cumhur İttifakı Türk-İslam Sentezcileri kapsamında değerlendirilmektedirler. Mamafih burada yaptığımız tipleştirme bir açıdan Weberyen tarzda ideal tip oluşturma olarak da değerlendirilmelidir. Bilindiği üzere, böyle bir tipleştirmede amaç, sosyal bilimlerin doğası gereği gerçekliği tümden kucaklamak olmayıp, gerçekliğe herhangi bir görüş açısından yaklaşırken onu anlamak ve çözümlemek için zorunlu olarak bir kılavuz veya araç oluşturmaktır (Demirel, 2013, s. 365).

Türk-İslam Sentezi'nin, bir vakıa olarak var oluşunun izleri Türklerin İslam’ı kabul ettiği dönemlere kadar sürülebilirse de ideolojik aygıt olarak Osmanlı Devleti'nin "beka" sorununa çözüm arayışı ortamında ortaya çıktığı söylenebilir. Daha sonraki süreçte de devletin "bekası" ve "selameti" Türk-İslam Sentezcilerinin en hassas noktaları, tutum ve politika belirlemede en etkili güdüleri olagelmiştir (Kadığlu, 2020, s. 815-816). Dolayısıyla devletin, Türk-İslam Sentezcileri için sentezi oluşturan iki unsurdan sonra en önemli kavram olduğu görülmektedir. Hatta işlevsel olarak, bu iki unsurun güçlü biçimde var olabilmeleri devlete bağl sayıldığından dolayı devletin kimi zaman daha ön plana çıktığı sezilmektedir. Nitekim Türk-İslam Sentezcilerine göre "Türk milleti, bekasını devletiyle bir görmüş" bir millettir (Niyazi, 1996, s. 9).

Bu durumun konjonktürel ve ideolojik/politik gerekçeleri mevcut olmakla birlikte Türk-İslam Sentezcilerine göre çok daha derin sosyolojik ve antropolojik gerçekler söz konusudur. Zira devlet, "tarihin her evresinde çeşitli şekil ve düzeylerde olmak üzere, toplumsal bir gerçeklik olarak daima var olmuştur. Bu yüzden felsefi antropoloji, onu insanın varlık şartlarından birisi olarak kabul etmiştir" 
(Kösoğlu, 1997, s. 14). Bu toplumsal ve antropolojik gerçekliğin nedenlerini ise insanların bir arada yaşamaya yönelik doğalarında aramak gereklidir. Onlara göre birlikte yaşamanın gerektirdiği temel kuralları aslında din ve ahlak koyar. Ancak tüm insanların dinin ve ahlakın her daim yaptırıma sahip olmayan, nispeten gönüllülük esasına dayalı kurallarına uymaları temin edilemez. Bundan dolayı beraber yaşamanın sonucu olarak ortaya çıkan beşerî ilişkileri maddi yaptırımlar uygulayarak düzene sokmak için örgütlenmiş güce ihtiyaç duyulmuştur ki, bu güç devlet ve hukuktur (Kösoğlu, 1997, s. 13).

Dolayısıyla Türk-İslam Sentezcilerine göre devlet/hukuk, ahlak ve din arasında çok yakın ve güçlü bir ilişki bulunmakta olup, bu kurumlardan her biri diğeri ile karşıllklı etkileşim içerisindedir (Kadıoğlu, 2021). Kimi devirlerde gerilimli bir mahiyet arz eden bu çok değişkenli ve katmanlı ilişkide, Türk-İslam Sentezcileri tarafından devlet, sahip olduğu kutsal veçhesiyle, çoğu zaman belirleyici konumda olmuştur.

Bir buçuk asra yakın bir süredir Türk düşünce ve siyaset hayatını etkileyen ana akımlardan biri olan Türk-İslam Sentezi, özellikle son elli yıldır devlet politikalarını yönlendirmekte, üretmekte veya uygulamaktadır. Bu nedenle günümüz Türkiye'sinde hukuksal, toplumsal ve dinsel hayattaki hem kendi doğal yatağında akarak süregelen hem de devlet eliyle yeni kanallar açılarak yönlendirilmeye çalışılan değişim ve dönüşümü açıklamak için Türk-İslam Sentezcilerinin devlet tasavvurlarının ve bu bağlamda din-devlet ilişkilerine dair görüşlerinin araştırılması bir zorunluluk taşımaktadır.

İşte, doktora tez çalışmamızdan üretilmiş olan bu makale, sözünü ettiğimiz zorunluluk doğrultusunda devletin mahiyetine ve din ile devlet arasındaki ilişkilere yönelik olarak Türk-İslam Sentezcilerinin görüş ve kabullerini konu edinmekte olup bununla sınırlandırılmıştır. Türk-İ̀slam Sentezcilerine ait eserler, çalışmamızın konusu ve sınırlılıkları doğrultusunda dolaylı gözlem yöntemiyle ele alınmıştır. Literatür taraması yoluyla ulaşılabilen kaynaklar derinlemesine incelenmiş, gözden geçirilmiş ve kuramsal bir derleme ile sunularak yorumlanmıştır.

\section{Türklerde devletin anlam ve önemi}

Devlet kavramı Türk-İslam Sentezinde gerek kuramsal/ideolojik açıdan gerekse pratik/politik açıdan önemli yer tutmaktadır. Güngör (1989, s. 138)'ün ifade ettiği üzere, Türk-İslam Sentezcilerine göre, "Bir yerde Türk varsa devleti de vardır, devleti yoksa Türk yoktur." Ona göre başka milletlerde devletin veya siyasal egemenliğin varlığı böylesine hayati önem taşımamaktadır. Bu durum ise dinden değil milli kimlikten kaynaklanmaktadır. Örneğin aynı dine mensup olan Araplarla Türklerin dinsel ve toplumsal yayılma yöntemlerinde farklılık vardır. Araplar başka topraklarda genellikle ticari yollarla kurduğu ilişkiler ve ağlar vasıtasıyla yayılırken, Türkler siyasi hakimiyet kurmadan varlıklarını devam ettiremezler, toplumu yönlendiremez ve yönetemezler, çünkü "Türk, kendi siyasî hâkimiyetinin bulunmadığı yerde yoktur.” (Güngör, 1989, s. 138).

Türk-İslam Sentezcilerinin devlet tasavvuru, insanların iradelerinin ürünü olup bir sözleşmeden doğan ve bireylere hizmet için var olan liberal devlet anlayışı ile üretim ve değerlerin dağılımının kendiliğinden, bir bask1 ve zorlama aracına gerek olmaksızın düzenleneceği komünizmin üst aşamasına geçildiğinde varlık nedeni ortadan kalkacağı için devletin kendisinin de ortadan kalkacağını söyleyen Marksist devlet anlayışına temelde zıttır. Yine onların devlet tasavvurları, bireylerin sırf insan olmaları nedeniyle başlı başına bir değer ve varlık sayılmayarak bunun yerine sosyal kuruluşların (korporasyonların) devletin temeli sayıldığı faşist/korporatif devlet anlayışına ve temel amacı irkı geliştirmek ve korumak olan nasyonal sosyalist devlet anlayışına da uzaktır (Göze, 2005).

Hegel'in, Tanrı'nın yeryüzündeki yürüyüşü olarak nitelendirdiği ve bu nedenle dünyevi bir tanrısallık olarak hürmet göstermemiz gerektiğini söylediği devlet (Hegel, 2003, ss. 279, 307), Türkİslam Sentezcilerinin devlet tasavvuru hakkında bize daha fazla şeyler söyler. Bu çerçevede Türk-İslam Sentezcilerinin konuyla ilgili sıkça telaffuz ettikleri mottolarından biri olan ebet-müddet devlet kavramı, devlete atfedilen dünyevi tanrısallığın bir işareti olarak yorumlanabilir. Aynı şekilde "din ü devlet" tabiri de bir arada söylenegelen iki kavramdan daha fazlasına göndermede bulunur. Bunlar, her ikisi de kutsal olan, hatta birbirlerinin desteğini zorunlu olarak gereksinen, çoğu defa birbiri yerine geçen iki kavramdır: 

ilişsilerí.

O kadar ki, din ve devlet aynı mana taşıyan birer mefhum hâline gelmiş, her türlü gayretin ve fedakârlığın din ve devlet uğruna yapılması bir nas olmuştur. Türklerin elindeki kılıç din ve devlet için çekilir, karşısındaki düşman da din ve devlet düşmanıdır. Devlet de din gibi "ebedmüddet"tir. ... İnsana her türlü rütbe ve makamı devlet verir, alan da yine devlettir. Bir Osmanlı çok defa "Allah'a can borcum var" yerine "devlete can borcum var" der. Devletin idaresine boyun eğmekle kazaya rıza göstermek aynı şeydir (Güngör, 1989, s. 138-139).

Bununla birlikte Türk-İslam Sentezcilerine göre böyle bir kutsal devlet telakkisi Türklerin İslam'a girmelerinden sonra ortaya çıkmış değildir. Müslüman olmadan önce de Türklerde devletin değer ve anlamı bu şekildeydi. İslam, kendinden önceki devlet anlayışını destekleyen doneleriyle Türklerin mukaddes devlet telakkisini sağlamlaştırmıştır. Zira İslâm'dan önce Türklerde devlet gücünün kaynağı tanrısal olarak kabul ediliyordu (Arslan, 1987, s. 77).

Eski tanrısallık, İslam'in kabul edilmesiyle bu yeni dinin özellikle gaza ve cihad ilkeleri etrafında yeni bir tanrısallığa evrilmiştir. Müslüman Türk devletlerinde devletin var olmasının ve savaşların temel amacının "ila-yı kelimetullah" (Allah'ın adını -ve dolayısıyla İslam'1- yüceltmek) şeklinde kavramsallaştırılması, eski kutsal/tanrısal devletin yeni dinin değerleri doğrultusunda evrilmesiydi. Bu evrilme sürecinde ise Türk töresi ortadan kalkmamış, devlet anlayışı iki temel üzerinde, Türk töresi ve İslam dini üzerinde yükselmiştir. Nitekim İslâm'dan önce büyük ve kudretli devletler kuran Türkler, İslâm'a girdikten sonra ise daha da büyük ve kudretli devlet ve medeniyetler kurmuşlardır. Diğer yandan, devletin bu şekilde milletle ve geleneklerle çok sıkı ilişkili biçimde anlaşılması, Türk-İslam Sentezcilerine göre ideal devlet sisteminin milli devlet olduğunun nedeni olarak kabul edilebilir. Hatta onlara göre devletin doğal biçimi, milli devlettir. Rejimin ne olduğu burada önemli değildir; devlet, milletin sahip olduğu inançlara ve milli iradeye uygunsa milli olarak nitelendirilir. (Türk Düşünce Hareketi, 2007, ss. 39-41).

Dolayısıyla milli devlet niteliğinde olduktan sonra, bir devletin monarşiyle, temsili seçim sistemiyle veya başka bir rejimle yönetilmesi Türk-İslam Sentezcileri için temelde bir farklılık oluşturmaz. Bu itibarla günümüzün çok partili sisteme dayalı devlet rejimi hem bu nedenle hem de nispi de olsa somut milli iradeyi yönetime taşıma potansiyeliyle Türk töresine ve İslam dinine daha uygun sayıldığından dolayı Türk-İslam Sentezcileri tarafından kötü görülmemektedir. Bununla beraber onlara göre çok partili sistemi oluşturan partilerin, milleti kamplara ayırıcı "dini ve felsefi” ideolojilere dayalı olmamaları, "kitle" partisi niteliğinde olmaları gerekmektedir (Arvasi, 1990, s. 117).

Ancak yine de, taşıdığ 1 tüm olumlu yönlerle birlikte, kavramsal ve sözlük anlamlarıyla az veya çok, önemli veya önemsiz de olsa ayrılık ve parçalanmaya göndermede bulunduğu gerekçesiyle siyasi parti olgusuna karşı Türk-İslam Sentezcilerinin soğuk bir tutum takındıkları söylenebilir. Gerek Türklerin ve Müslümanların yüzyıllardır yaşadığı tarihi tecrübelerin gerekse İslami nasların birlik olmaya ve parçalanmamaya yaptığı 1srarlı vurgunun bu tutumu beslediği görülmektedir (Türkdoğan, 2004, ss. 532-533). Bu sebeple partilerin ve hatta parlamentonun gücünün zayıf olduğu ve bu haliyle Türk tarihindeki geçmiş yönetim modellerini hatırlatan başkanlık sistemine karşı daha sıcak bir tutum içerisindedirler (Arvasi, 1980, s. 381).

Buraya kadar anlatılanlardan, Türk-İslam Sentezcilerinin devlet kavramına bakışlarının ve devlet tasavvurlarının ne olduğu hususunda bir mesafe almış olsak da, onların devleti derli toplu biçimde ve bir cümle halinde nasıl tanımladıklarını henüz ifade etmedik. Tanım yapma dediğimiz işlemin, nihayetinde bir sınırlama yapmak ve tanımlanan varlığın işlevselliğine göndermede bulunmak olduğu göz önüne alındığında, devlete hep kutsal bir yön atfeden Türk-İslam Sentezcilerinin bu itibarla devleti tanımlamaktan ziyade anlatmaktan yana oldukları görülmektedir. Mamafih konuya dair Devlet isimli müstakil bir eser kaleme alan Kösoğlu (1997, s. 32)'nun yaptığı şu tanım, Türk-İslam Sentezcilerine göre devlet olgusunun niteliklerini gösterme noktasında eksiklikler taşısa da, onların işlevsel açıdan devleti nasıl tanımladıklarını bize sunmaktadır: "Devlet, insanlar arasında adaleti kurmak amacina yönelik toplumsal bir teşkilatlanmadır." 


\section{3. İslam ve demokrasi}

Düşünce ve uygulama olarak kökenleri M.Ö. beşinci yüzylldaki Antik Yunan şehir devletlerine kadar giden demokrasi, özellikle 1789 Fransız İhtilali'nden sonra gerek bir yönetim biçimi olarak siyasal sistemler üzerinden gerekse bir yaşam biçimi olarak toplumsal yapı ve değerler üzerinden tüm dünyayı etkisi altına almıştır. Gittikçe politik ve toplumsal bir erdem halini alan demokrasi, o kadar çok sayıdaki siyasal sistem ve ideoloji tarafından sahiplenilmiştir ki, gerçekten de kelimenin gündelik kullanımının fiilen anlamsızlaşmaya yüz tuttuğu iddia edilebilir. Nitekim her türlü siyasal uygulamanın, sistemin, ideolojinin, kendilerini meşrulaştırmak için demokrasi kavramına başvurması çok sık rastlanılan bir durumdur (Marshall, 1999, s. 140).

Türkiye de bu durumdan uzak kalmamıştır. Osmanlı Devleti'nin yıkılışına doğru ülkeyi yıkımdan kurtarmak için politik ve fikri arenada öne çıkan ve Türk-İslam Sentezcilerinin düşünsel öncülleri olarak nitelendirilebilecek olan Türkçüler ve İslamcılar, İslam devlet idaresinde ve Türk devlet geleneğinde Kur'an'dan alınan bir terim olarak "şura" prensibine yaptıkları atıfla geleneksel Türk-İ̀slam devlet anlayışının zaten demokrasiyi barındırdığını iddia ediyorlardı (Kabaklı, 1990, s. 28).

Bu iddia Türk-İslam Sentezcileri tarafından da aynı şekilde kabul görmüştür. Onlara göre Türk ve İslami devlet geleneği teoride ve pratikte demokratik yönetim aygıtlarının birçoğuna zaten sahipti. Batı dünyasından yüzyıllar önce İslam tarihinde $\mathrm{Hz}$. Muhammed ile dört halife döneminde kadına oy hakkı verilmesi, devlet başkanını seçmede seçim usulünün uygulanması, parlamento görevini gören şura meclislerin oluşturulması gibi hususlar bu iddianın kanıtlarıdır. Dolayısıyla demokrasinin toplumda ve devlet yönetiminde hâkim kılınması aslında milli ve dini öze dönmek anlamına gelir (Kurtkan, 1977a, s. 2).

Aynı şekilde Türk-İslam Sentezcileri demokrasi kavramının karşıllı̆ı olarak cumhuriyetin de, Türk kültür geleneğinde bin yılı aşkın süredir yer etmekte ve Türk düşünce sisteminde varlığını göstermekte olduğunu, Türklerin İslâmiyet'i kabul süreciyle demokratik devlet anlayışı ve tutumlarının etkinlik kazandığını ileri sürmektedirler (Türkdoğan, 2004, s. 532).

Türk-İslam Sentezcilerine göre Türk-İslam geleneği demokrasinin sadece yönetsel aygitlarına değil, toplumsal düzlemdeki değer ve gerekliliklerine de sahiptir. İnsan hakları, eşitlik, adalet, özgürlük kavramları ve bunları hedef tutan değer hükümleri ile sosyal gelişme bakımından taşıdıkları önem, sosyal bilimler tarafindan ortaya konmazdan çok daha önce Türk-İslam devlet anlayışında ve birikiminde kendilerini göstermişlerdir. Türk-İslam toplum yapısı orta sınıflaşmaya, sosyal bütünleşmeye ve insanlar arasında eşitlik sağlamaya imkân veren geleneksel değerleriyle demokratik toplumun bileşenlerini yüzyıllardır içerisinde barındırmaktadır (Kurtkan, 1977b, s. 10).

Özellikle günümüzün demokrasi anlayışının en önemli bileşenlerinden biri olarak kabul edilen özgürlük, İslam'ın gerçekleştirmeye çalıştığı temel amaçlardan biridir. Hatta Ziya Gökalp'e göre İslam dini özgürlüğe o kadar çok önem vermektedir ki, İslamiyet'in Allah'a ibadetten sonraki en büyük parolası özgürlüktür:

Din-i İslâm, sâliklerini kuyûd-i mâsivâdan tecrîd eden bir din-i hürriyet-perverânedir. İslâmiyet'in üss'ül-esâsı olan Tevhîd, yalnız Rabb-i Vâhid'e kul olmak, başka rablar tanımamak demektir. Hulâsa-i kelâm, bizim iki büyük vazîfe-i diniyemiz vardır ki birincisi, Halika karşı abd vazifesinde, ikincisi, mahlûkata karşı hür heyetinde bulunmaktır. O halde Ehl-i-İslâm'ın ibâdetten sonra en büyük şiarı hürriyettir (Gökalp, 1994, s. 97).

Bununla birlikte Türk-İslam Sentezcilerine göre bu özgürlük sınırsız değildir. En geniş sınır çizgisini "Allah'tan başkasına kul olmamak" ilkesinin oluşturduğu dini ve milli değerler, bireyin özgürlüğünün sınırlarını ve içeriğini belirler. Bu nedenle özgür birey yaşadığı topluma "kafa tutan", yani toplumun dini, milli, ahlaki, hukuki değerlerine ters düşen birey olamaz. Zira bireylerin toplumsal değerlere ters düşmelerine yol açan veya müsaade eden özgürlük anlayışı, insanların, içinde yaşadıkları toplum içinde yalnızlaşmalarına ve yabancılaşmalarına neden olur. $\mathrm{Bu}$ durumun ise hem ferdin kendisine hem de topluma zarar verdiği ve vereceği açıktır (Arvasi, 1979, ss. 22-23).

Modern demokrasilerde özgürlük alanlarından, Türk-İslam Sentezcilerini en çok ilgilendirenlerin başında din ve vicdan özgürlüğü gelmektedir. Düşünce özgürlüğünün de kendisine 


\section{Kadioğlu, A. S. (2021). Türk-islam sentezcilerinde devlet tasavvuru ve din-devlet ilişkilerí.}

eklendiği din ve vicdan özgürlüğü onlara göre bir ülkede demokrasinin gerçekten var olup olmadığının göstergesidir. Arvasi (1996a, s. 63), bu hususu şöyle ifade etmektedir: "Demokrasi, bir haklar ve hürriyetler nizamıdır. Hürriyetlerin temeli de "fikir ve düşünce", "din ve vicdan hürriyeti"dir. Bir ülkede "demokrasi”"nin var olup olmadığını mı öğrenmek istiyorsunuz? İlk yapacağınız iş, o ülkede bu iki temel hürriyetin durumunu objektif olarak tespit etmektir."

Bu açıdan bakıldığında Türk-İslam Sentezcilerine göre İslamiyet ve dolayısıyla İslami devlet, din ve vicdan hürriyeti konusunda her şeyden evvel insanların kendi dini inançlarını tercih ederken bireysel iradeleri doğrultusunda özgürce hareket etme serbestliğini ve bireysel sorumluluğu kabul ettiğinden dolayı demokratik anlayışı kendi içinde ve özünde barındırmış olmaktadır (Arvasi, 1996a, s. 106).

Nitekim İslam devletinin ilk nüvesini teşkil eden Hz. Muhammed ve dört halife dönemlerinde Türk-İslam Sentezcilerine göre, bir değer hükmü olarak İslâm dininin özünde bulunan demokrasiye tam bir titizlikle sadakat gösterilmiş̧tir. İslâm peygamberi, yaşadığı çağın ve coğrafyanın özellikleri gereği dini ve dünyevi liderliği bir arada yürütmüş olsa da, dünyevi liderliği için insanların bey'at olarak adlandırılan onay ve reyine başvurmuştur. Ondan sonra gelen ilk dört halife de Hz. Muhammed'in bu şekildeki demokratik uygulamasını devam ettirerek devlet başkanlığı görevi için halkın onay ve oyuna başvurmuşlardır. Ancak ilk dört halife döneminden sonra İslâmiyet'in özünde mevcut olan demokrasinin terk edildiği görülmektedir. Bununla birlikte, İslâmiyet'in diğer bütün kıymet hükümlerine sımsıkı bağlı kalındığı zamanlarda İslam'ın özünde var olan demokrasi, doğrudan veya dolaylı biçimde kendini gösterebilmiştir. Örneğin bir İslam devleti olarak Osmanlı Devleti’nin yükselme devrinde, demokrasiye bağlı olunmamakla beraber, diktatörlüğe de kaymamak başarısı gösterilebilmiştir (Kurtkan, 1977b, ss. 49-52).

Dolayısıyla Türk-İslam Sentezcilerine göre, İslam peygamberinin Medine'de kurduğu ilk İslam Devletinde belki de dünyanın ilk ve mükemmel demokrasisini gerçekleştirmesinde (Arvasi, 1996a, s. 103) görüldüğü üzere, İslamiyet demokrasinin var olması için gerekli değer hükümlerine sahiptir. Zira, "Demokrasi ve demokratik bir ortam içinde ferdin ve cemiyetin birlikte gelişmesi açısından, en fazla ve en iyi rol ifa edebilecek İslami değerler ferdin ferdiyet seviyesine ulaşması hususunda etkili olabilecek değerlerdir. İslamiyet böyle bir değerler sistemine kucak açabilecek bir kültürün potansiyel hazinesidir" (Kurtkan Bilgiseven, 1995, s. 74).

Bununla beraber Türk-İslam Sentezcileri, çağımızın yaygın demokrasi anlayışları olan liberal demokrasi ve sosyal demokrasi ile İslam dininin içinde barındırdığını söyledikleri demokrasi anlayışı arasında, dayandıkları temel dünya görüşü açısından önemli bir fark olduğunu da belirtirler. Liberal demokraside daha çok bireysel hak ve özgürlükler, sosyal demokraside ise daha çok toplumsal hak ve menfaatler ön plana çıkar ve ağırlı̆̆ını hissettirirken; İslamiyet'te söz konusu olan demokratik anlayış, bireysel veya toplumsal menfaatlerin ötesinde ve bunları birlikte içeren ilkelere dayalı bir sisteme dayanmaktadır. Bu ilkeler ise Allah'ın peygamber vasıtasıyla ilettiği hükümlerdir (Arvasi, 1980, s. 328).

\section{Hilafet kurumu}

Hilafet (Halifelik) konusu, Türk-İslam Sentezcilerinin, nicelik ve nitelik itibariyle sınırlı da olsa İslameı reaksiyonlarının görülebildiği ve kendi aralarında farklılaşabildikleri konulardan biri olarak dikkat çekmektedir. Hilafet kurumunun ümmet olgusuna kuvvetli vurgu yapması, din ve devlet ilişkilerinde sınırları belirsizleştirmesi, nasıl ve neden kaldırılmış olduğu, kaldırılmasının yol açtığı sorunlar yahut vesile olduğu faydalar gibi hususlar bu farklılaşmayı beslemektedir. İslamcı reaksiyonu paylaşmayanlar temel olarak hilafetin ileri sürüldüğü kadar önem taşımadığı, dini açıdan varlığının zorunlu olmadığı, zaten kaldırıldığı zamanki vaziyeti bakımından işlevsiz hale geldiği gibi iddialarla bu tutumlarına destek bulmaya çalışmaktadırlar.

İslamcı reaksiyonu paylaşmayanların halifelik kurumuna ilişkin öncelikli tespitleri, hilafetin dini değil, dünyevi otoriteyi içermesiydi. Zira Hz. Muhammed son peygamber olduğuna göre, dini otorite bakımından kimsenin ona vekil (halef) olması mümkün değildi. Bu sebeple de halifeler ancak İslam Devleti'nin başı olarak ona halef olabilirdi. Bu haleflik için gerekli ve yeterli şart ise devleti İslam esaslarına göre yönetmekten ibaretti. Dolayısıyla hangi devlette ve hangi milletten olursa olsun İslam 
esaslarına göre yönetim biçimini benimsediği sürece her devlet başkanı halife unvanını alabilirdi (Güngör, 2005a, s. 169).

Hatta Kurtkan (1977a, ss. 191-194)'a göre, Hz. Muhammed ve Dört Halife dönemleri dikkate alındığında, hilafetin aslında seçim esasına dayalı olan ve babadan oğula geçmesi mümkün olmayan siyasi ve idari bir makam olduğu görülür ki, bu açıdan dünyevi işlerin yönetimi anlamında halifeliğin, halkın vekaleti makamından ibaret olduğu bile söylenebilir. Dini bakımdan halifelik ise Kur'an'dan alınan anlamıyla Allah'ın yeryüzündeki vekili olmak demektir ki, bu vekilliği en güzel bir şekilde Hz. Muhammed ifa etmiş olup, dinen ve ahlaken onun gibi hayat sürebilen her fert Allah'ın yeryüzündeki halifesi olabilir. Bununla birlikte hilafet makamının yüzyıllar içinde kazandığı ve özellikle II. Abdülhamid'in Panislamcı politikalarıyla Osmanlı'nın son zamanlarında etkinliği hissedilen, dünyadaki tüm Müslümanların dini ve dünyevi temsilcisi ya da lideri olma konumu da o zaman için yadsınamaz bir vakıadır. Ancak günümüz siyasi şartlarının, çağcıl iktidar telakkilerinin ve modern insanın yönetim tasavvurunun geldiği nokta, o zamanki hilafet anlayışı ve halife portresiyle çizilen yönetim ve iktidar anlayışının çok fazla uzağına düşmektedir.

Yukarıda çağdaş dünyanın siyaset anlayışından uzak düştüğü ifade edilen hilafet anlayışının iyi bir örneğini Gökalp'te bulabiliriz. Gökalp, İslam dininde en önemli ibadetlerden biri olan namaz örneğinden yola çıkarak halifenin konum ve önemini izah eder. Bilindiği gibi İslam'da namazların bir imamın arkasında cemaatle kılınması asıldır. Cemaati oluşturan fertler imama uyar, böylece imam cemaatin simgesi olur. Fertler arasındaki dayanışma imamın şahsında tecelli ederek, o namaz cemaati tek bir ruh haline gelmek suretiyle küçük bir dayanışma ortaya çıkar. İslamiyet'te bu küçük dayanışmadan başka bir de büyük dayanışma vardır ki, Müslümanların hepsini tek bir ruh haline getirir. $\mathrm{Bu}$, bütün imamların manevi olarak en büyük imama uymasıyla olur. İşte bu imamların imamına halife denir. Namazda imamın, cemaat olma bilinci ve kendisine uyanların her biri için taşıdığ büyük önem, halife açısından da ayrı ayrı tüm Müslümanlar ve Müslüman toplumlar ile İslam birliği için geçerlidir. Hatta daha da ötesinde Müslümanların birlik ve dayanışması, halife olmaksızın mümkün değildir. Dolayısıyla Müslümanlar ve Müslüman toplumlar için halifenin varlığı zorunludur (Gökalp, 2007a, s. 311).

Halifeliğin Müslümanlar ve İslamiyet için böylesine kritik önem taşıdığına dair tutumun Türkİslam Sentezcilerinin bir kısmınca hep paylaşılması, halifeliğin kaldırılmasına yönelik tepkilerin kaynağı olagelmiştir. Örneğin Kabaklı, Hilafetin Batılılar tarafından kaldırılmasının İslam ümmeti arasındaki birlik ve dayanışmayı ortadan kaldırdığını, özellikle Türkiye ile diğer Müslüman dünya arasına aşılamayacak sınırlar koyduğu iddia eder. Üstelik bu Müslüman dünya sadece Sünnilerden oluşmamaktadır. Şii Müslümanlar da halifeliğin Siyonizm ve emperyalizme karşı tüm Müslümanların sığınă̆ 1 olması nedeniyle hilafetin kaldırılmasından rahatsız olmuşlardır. Ona göre Halifeliğin kaldırılması, Türkiye'nin diğer Müslüman toplumlarla ilişkisini bozduğu gibi, Türkiye'de yaşayan ve kendilerini, -aynı dinden olma anlamını da barındıran- "milliyetçe Türk" olarak kabul eden farklı etnik kökenli dindaşların bu kabullerinin de sarsılmasına sebep olmuştur. Zira hilafet, özellikle Osmanlı Devleti uygulamasında etnik kökeni aşan bir anlama sahip olup yine böyle aşkın bir birliği ifade ve temin ettiği için onun kaldırılması, Türkiye'de bu birliğin de kalkması ve Türklerle diğer Müslüman tebaayı eşit kılan unsurun yok edilmesi anlamına geliyordu. Dolayısıyla Kabaklı, halifeliğin kaldırılmasının her açıdan yanlış olup, hiçbir fayda sağlamadığı gibi çok sayıda zarara neden olduğunu, bu zararların günümüze kadar devam eden ve bundan sonra da devam edecek olan etkilerinin hem iç politikada hem dış politikada sürekli olarak kendini göstermekte olduğunu iddia eder. Ancak ona göre de tüm bunlara rağmen artık hilafeti geri getirmek düşünülemez. Yapılması gereken şey, hilafetin kaldırılmasından dolayı oluşan zararları gidermek için neler yapılabileceği üzerinde düşünmektir (Kabakl1, 1990, ss. 170-182).

\section{Din-devlet ilişkileri}

Din-devlet ilişkilerinin, toplumların din ve devlet algıları ile din-devlet ilişkilerine dair tarihi tecrübe ve birikimleri doğrultusunda şekillendiği ve değerlendirildiği bilinmektedir. Türk-İslam 


\section{Kadioğlu, A. S. (2021). Türk-islam sentezcilerinde devlet tasavvuru ve din-devlet ilişkilerí.}

Sentezcilerine göre Batı Avrupa tecrübesinde, özellikle Katolik Kilisesinin devletten bağımsız ve hatta devlete egemen biçimde kurumsallaştığı yer ve zamanlar göz önüne alındığında, din-devlet ilişkileri genellikle çatışmalı bir alana tekabül ederken; dünyanın başka çoğu ülkesi için böyle bir durum geçerli değildir. Bu bağlamda Yunanistan ve İsrail devletleri, "Batılı" oldukları halde din-devlet ilişkilerinde dinin ağırlığının ve üstünlüğünün mevcut olduğu, teokratik denebilecek örnekler olarak dikkat çekmektedir (Arvasi, 1990, s. 183).

Türk-İslam Sentezcilerine göre İslamiyet söz konusu olduğunda din ve devlet ilişkilerinde, yukarıda değinildiği gibi, kutsallık veçhesinden niteliksel olarak benzeşen iki olgunun temelde gerilimli değil, uyuşumlu bir ilişkisinden bahsedilebilir. Sözü edilen kutsallı̆̆ıla devlet, diğer iki kutsal olgu olan din ve milletle beraber Türk şuurunu meydana getiren üçlü birleşimin bir öğesidir. Öyle ki, bunlardan biri olmadan diğer ikisi de olamaz (Türk Düşünce Hareketi, 2007, s. 137).

Ruhban sınıfı ile iktidarından ve teokratik yönetim biçimine yol açacak diğer koşullardan uzak olan İslam dini, bireysel ve toplumsal hayatın her sahasında özellikle ve öncelikle ahlaki açıdan etkili olmaya çalışan mahiyetiyle, Kurtkan (1977a, s. 209)'a göre devleti doğrudan yönetmek yerine devlet yöneticilerini sürekli bir otokontrolle birlikte hukuki ve ahlaki davranmaya zorlayarak, "resmi hukuku anarşiye sürüklemek şöyle dursun", uluslararası düzeyde dahi hukukun üstünlüğünün sağlanmasına yönelik büyük potansiyel taşımaktadır. Nitekim Hz. Muhammed'in dini ve dünyevi liderliği bizzat yürüttüğü dönemde bu potansiyel açıkça gözlemlenebildiği gibi (Kurtkan, 1977a, s. 187) Türklerin Müslüman oldukları devirler de bu potansiyelin ortaya çıktı̆̆ örnek dönemler olarak görülmektedir (Güngör, 2005a, s. 178).

Türk-İslam Sentezcilerine göre günümüzde daha çok İslam ve İslam devletleri ile özdeşleştirilen teokrasi, aslında Avrupa ve Hristiyan devlet tecrübesinin ürünü olup, bunun Türk ve İslam devlet tasavvuruyla direkt olarak ilişkilendirilmesi mümkün değildir. Doğrudan doğruya bir ruhbanlar iktidarı anlamına gelen teokrasi sayesinde Kilise, Avrupa'da yüzyıllar boyunca devletleri yönetmiş, krallıkların kontrol ve hakimiyetini elinde tutmuştur. 17. yüzyıldan itibaren Kilise'nin toplumsal ve yönetsel etkisi gittikçe azalmaya başlamış, teokratik devlet uygulamaları teker teker son bulmaya başlamıştır. İslam devlet tecrübesinde ise, İslam'da müesses ruhban sınıfının olmaması ve din adamlarının genel olarak devlete tabi olması nedeniyle ruhban sınıfinın iktidarı anlamında Avrupa'daki gibi teokratik devlet pratiği mevcut olmamıştır. Zaten İslam dininin ana referans kaynakları da teokrasinin var olmasına uygun bir fikri altyapıyı sunmazlar (Arvasi, 1991, ss. 122-123).

Bununla birlikte, devlet başkanının aynı zamanda başrahip olması sebebiyle bilhassa Uygur ve nispeten Hun devlet idaresi uygulamalarına bakıldığında, "İslam öncesi Türk devletlerinde teokrasiye benzer bir yapı"nın bulunduğu, ancak İslamiyet'in kabulünden sonra İslami esasları kabul eden Türk devletlerinin hiçbir zaman teokrasiyi andırır bir yapıya sahip olmadıkları ifade edilmelidir (Niyazi, 1996, ss. 191-195). Keza İslam öncesi Eski Türk devlet anlayışına göre siyasal iktidarın Tanrı tarafından verilip yine Tanrı tarafından geri alınabileceğine ilişkin inanış da, İslam öncesi Türk devletlerinde teokrasiye benzer bir yapının bulunduğunu göstermekteyse de, bu, tanrısal bir misyon hukukuna işaret etmekte olup İslam öncesi dönemde Türk siyasi birliklerinin teokrasi olarak nitelendirilmelerine gerekçe yapılamaz (Arslan, 1987, ss. 79-81).

Dolayısıyla Türk-İslam Sentezcilerine göre, Türkiye'de belli kesimler tarafından sıkça ileri sürülen teokratik devlet düzeninin getirileceğine dair iddiaların ve ortaya konulan kaygıların herhangi bir dayanağı yoktur. İslam toplumlarındaki devlet ve din-devlet ilişkilerine dair kadim gelenek, teokratik devletin oluşmasına izin vermediği gibi, Türklerin tarihten gelen devlet tecrübesi de teokratik devletin oluşabilmesi için gerekli şartları barındırmamaktadır (Arvasi, 1990, ss. 234-235).

Türkiye'de oluşturulmaya çalışılan teokratik devlet veya şeriat korkuları ile genel olarak pek çok ülkede dindarlar ve din adamları üzerinden yapılagelen dinin siyasete alet edilmesi suçlamaları Türk-İslam Sentezcilerine göre başka neden ve amaçlara dayanmaktadır. Bilindiği üzere dünyanın hemen her bölgesinde ve hem günümüzde hem de geçmişte devlet yöneticileri dinin siyasete alet edilmesi, din ve mezhep kavgası gibi suçlamalarla din adamları üzerinde yıldırma politikaları uygulamışlardır. Bunların hemen hepsinde asıl gaye, din ile siyasetin birbirinden ayrılması değildir. $\mathrm{Bu}$ yıldırma ve baskı politikalarının asıl amacı din adamlarının siyasi iktidara karşı gelişebilecek muhalefete önderlik veya yardım etmelerini engellemek, onlar dolayısıyla iktidara yönelecek tehlikeleri önlemektir. 
Eğer dinin siyasete alet edilmesi ya da din adamlarının siyasi muhalefete destek veya önder olma potansiyelleri siyasi iktidar için tehlike teşkil etmeyecek kadar önemsiz olsaydı, dinle siyaseti birbirinden ayırmaya veya din adamları üzerinde baskı kurulmaya çalışılmazdı. Bu nedenle esas mesele din değil, dinin dolaylı veya dolaysız olarak sahip olduğu sosyal kuvvettir. Bu kuvvetin Batı ülkeleriyle onlar dışındaki ülkelerde geçirdiği değişim ve dönüşüme bakıldığında, her iki dünyada din adamlarına karşı takınılan tavır farklılıklarının kökü de anlaşılabilir (Güngör, 1993, s. 364).

Türk-İslam Sentezcilerine göre sosyolojik gerçeklikleri, toplumsal yapıyı ve bu yapının işleyişini nesnel olarak kabul eden devlet yöneticileri, kendilerinin dini inançları olsun veya olmasın, bir sosyal kurum olarak konumu, işlevleri ve etkileriyle din olgusunu inkâr edemeyecekleri gibi ihmal de edemezler. Keza insanların, toplulukların ve toplumların dinleri yokmuşçasına davranamazlar. $\mathrm{Bu}$ nedenle de siyasi iktidarlar teokratik devletin geleceğine ilişkin korkuları yayarak veya destekleyerek dinlerin eğitim ve öğretim faaliyetlerini, teşkilatlanmalarını, sosyal hayat üzerinde etkili olmalarını engellemeye çalışmamalıdırlar (Arvasi, 1989, s. 324).

Konuya bu açıdan bakıldığında Türk-İslam Sentezcilerine göre İslam'da din ve devlet arasında temelde hegemonik bir ilişkiden söz edilemez. Zaten bu nedenle Türkiye'de teokratik devlet tehlikesi de esasen mevcut değildir. Nitekim bizzat İslam Peygamberi Hz. Muhammed'in din-devlet ilişkilerine dair uygulamalarında devletin ve dinin, birbirlerinin hegemonyası altına girdiği görülmemektedir. $\mathrm{O}$, devleti ve dini birbirlerinin faydasına olmak üzere kullanmış, dünyevi liderlikle dini liderliği birbirinden ayırmıştır:

İslam Peygamberi kendi zamanının tarihi ve sosyolojik şartlarından doğan zorlayıcı tesirler altında: 1- Devlet müessesesine hayatiyet kazandırabilme hususunda dini, 2- Dinin devamını temin hususunda ise devleti, vasıta kılmak suretiyle dini ve dünyevi liderlikleri sırf kendi hayatına inhisar eden bir terbiyevi süre boyunca kendi şahsında birleştirmiş, fakat dünyevi liderliği ile dini liderlik vasfını hiçbir zaman birbirine karıştırmamıştır (Kurtkan, 1977a, s. 189).

Kurtkan'a göre, bu durumun en açık delillerinden biri Hz. Muhammed'in bey'at kurumunu getirmiş olmasıdır. O'nun, dini lider olarak İslam dininin insanlık ve insanlar için getireceği yararları ortaya koyduktan sonra, dini liderliği için hiç kimsenin onayına başvurmamışken, dünyevi işlerin idaresini üzerine almak için kadınlar dahil bütün yetişkin fertlerin bey'atını, yani kendisine oy vermelerini istemiş olması, din ve dünya işlerini ayrı değerlendirdiğini gösterir (Kurtkan, 1977a, s. 189).

Türkdoğan (2004, s. 533)'a göre, hayatı bütünsel bir açıdan ele alan İslam, hakimiyet meselesine de bütünsel açıdan yaklaşmakta olup, "Allah-merkezli" bir hakimiyet sistemini ileri sürmektedir. $\mathrm{Bu}$ nedenle de din ve devletin birbirinden ayrı güç olmalarına, Hristiyanlıkta olduğu gibi kilise ve devlet tarzında bir ayrılığa karşıdır. İslâm'a göre kâinatın tek bir idarecisi ve tek bir güç merkezi vardır, bu da Allah'tır. Bununla birlikte hakimiyetin bu şekilde konumlandırıldığı devlet yapısının teokratik düzeni çağrıştırdığı veya ima ettiği ileri sürülebilirse de bu kesinlikle doğru değildir.

Hakimiyetin Allah'a ait olduğu şeklindeki İslami söylemin, devletin yönetimi konusunda pratik ve reel açıdan uygulanabilir olmaktan ziyade, Müslümanlara ve Müslüman yöneticilere itikadi ve ideal açıdan yol gösterici nitelikte olduğu bilinmektedir. Yani bu söylemle İslam devletinde yöneticilerin ve yönetilenlerin sürekli olarak bu gerçeğin bilincinde olmaları amaçlanmaktadır. Yoksa devlet yönetimi manasında hakimiyeti Allah'ın kullanması zaten imkansızdır. Burada önemli olan nokta, hakimiyetin Allah adına da kullanılmasının imkânsız olduğudur. Öyleyse ne asaleten ne de vekaleten hiçbir kişi ve zümre kendini devlet yönetiminde mutlak hakimiyet sahibi veya ortağı göremez. Aksi halde istibdat ve dikta rejimi kaçınılmazdır ki İslam'ın buna karşı olduğu Türk-İslam Sentezcilerince 1srarla vurgulanır (Arvasi, 1996a, s. 90).

Bu cihetle, Türk-İslam Sentezcilerine göre devlet yönetimine ve din-devlet ilişkilerine yönelik İslami hükümler, dinin itikada ilişkin hükümlerinden değil, muamelata ilişkin hükümlerindendir. Öyleyse geçmişte veya günümüzde bazı koşullar altında din ile devletin birleşik halde bulunmasını, hatta devletin tamamen dinsel bir mahiyette olmasını gerektiren hükümler bulunabilir. Ancak bu hükümler dinin değiştirilemez nitelikteki inanç esaslarına değil, zamanın ve hayat şartlarının değişmesiyle değişen muamelat kısmına ait olduğu için toplumdan topluma, çağdan çağa değişebilir. Geçmişte dini ve dünyevi liderlikleri şahsında birleştirmiş olan devlet yöneticilerinin olması, bugün de bu şekilde dini ve dünyevi liderliğin birleşmesini icap ettirmez (Kurtkan, 1977a, s. 211). 


\section{Kadioğlu, A. S. (2021). Türk-islam sentezcilerinde devlet tasavvuru ve din-devlet ilişkilerí.}

Burada, Türk devlet geleneğinin tüm tarihine bakılacak olduğunda dini ve dünyevi liderliklerin birleştirilmesi uygulamasının, yukarıda da temas ettiğimiz üzere, Türklerin İslam dinine girdikten sonra edindikleri bir tecrübe olmadığı özellikle ifade edilmelidir. Gökalp, Çarlığın yıkılmasının akabinde Rusya'daki Türklerin siyasi teşkilatlanma konusunda nasıl hareket etmeleri lazım geldiğine dair görüşlerinde, İslam öncesi eski Türklerde devlet yöneticilerinin İslam'da da görüldüğü gibi dini ve dünyevi liderlikleri kendi şahıslarında birleştirdiklerini söyleyerek, Rusya'daki Türklere dini ve dünyevi liderlik ayrımına dayalı bir siyasi teşekkülü önermemekte, atalarını takip etmek suretiyle dini ve dünyevi liderliği birleştirip büyük bir devlet kurmalarını salık vermektedir (Gökalp, 2007b, s. 36).

Din ve devlet ilişkileri kapsamında temas edilmesi gereken önemli konulardan biri de günümüz demokrasilerinin ana bileşenlerinden olan siyasi partilerin İslami açıdan durumu, daha spesifik olarak ifade edersek "dini parti” olgusudur. Arvasi (1996b, s. 167-169)'ye göre, İslam dininin özellikle ahlaki ve insani değerlerini hayata geçirmeyi amaçlayan partiler veya bu amacı benimsemiş kişilerin kurduğu ve yönettiği partiler olabilirse de kendilerini "İslami/dini parti" olarak sunan siyasi parti oluşumları İslamiyet' in özüne aykırıdır. Zira öncelikle İslam, dinde firkalaşmaya, yani dini partiler kurmaya izin vermemektedir. İkinci olarak İslamiyet'i, bir siyasi parti hareketi biçiminde ortaya koymaya çalışmak, aynı zamanda onun evrensel ve siyaset üstü karakterini yok etmeye, yani bizzat dini tahrip etmeye çalışmak anlamına gelir. Dini partilerin kurulması halinde mezhepler, tarikatlar ve dini gruplar politize olacak, birbiriyle çatışan fraksiyonlar doğacak, dini ve toplumsal hayat çatışma içerisine düşecektir. Din, kutsal kimliğini yitirecek, alelade bir siyasi harekete dönüşecektir. Bazı Müslüman aydınların İslam’a hizmet konusunu sadece bir siyaset sorunu olarak değerlendirmeleri, Müslümanların siyasi olarak örgütlenmedikçe başarılı olamayacaklarına ilişkin düşünceleri yanlıştır. Çünkü İslamiyet, siyasete öncelikli bir yer vermez, onu araç olarak görür; siyaset, İslam'ın çok yönlü nizam ve programının sadece bir yönünü teşkil etmektedir. Dini parti olgusu, İslam’ı siyasi kavgalar zeminine çekeceği için, bundan kaçınılmalı, bilhassa Müslüman aydınlar dini politize etmeye kalkışmadan, toplumsal hayatın her alanında ağırlıklarını hissettirmelidirler.

\section{Laiklik}

Türk-İslam Sentezcilerine göre laiklik konusunda ilk ifade edilmesi gereken husus, laikliğin esas olarak Hristiyanlığa ve Hristiyan toplumlara özgü olduğudur. Ünlü Fransız sosyoloğu Durkheim'ın dini tanımlarken esas aldığı "bir kutsala inanç" fikrinden hareket edilirse, Hristiyanlıkta kutsal (sacred) ve kutsal dışı (propane) olmak üzere iki tane varlık alanının mevcut olduğu görülmektedir ki, işte lâiklik, Hristiyanlıkta bu kutsal-dışı alanı belirler. İslam dininin varlık anlayışında ise böyle kutsal ve kutsaldışı şeklinde ikili yapı yoktur. Yani İslamiyet, Hristiyanlıktaki gibi bir varlık anlayışı benimsemediği için, o varlık anlayışının doğal bir uzantısı kabul edilebilecek olan laiklik kavramına uzaktır. Bu nedenle Türkiye'de laiklik kavramını ilk kullanan düşünürlerden olan Gökalp, laikliği "ladini” (dini olmayan) olarak çevirmiştir. Binaenaleyh laiklik, Batı toplumlarına ait olan ve temelinde Hristiyan varlık anlayışı ve düşünce sistemi bulunan bir kavramdır (Türkdoğan, 2004, s. 533).

Laikliğin gerek kaynak dilinde gerekse ladini şeklindeki ilk Türkçe karşılı̆̆ında "dine karşı, düşman veya aykırı" manasına gelmediğini, dine "ilgisiz, yani din sahasının dışında" anlamı taşıdığını Türk-İslam Sentezcileri özellikle vurgulamak isterler. Laiklik hem bu geniş anlamıyla hem de "papazlar sınıfina mensup olmayan, ruhbandan olmayan" şeklindeki dar anlamıyla Hristiyan medeniyetine ait bir kavramdır. Bilindiği gibi İslam'da ruhban sınıfı yoktur. Dolayısıyla aslında laiklik de laikliği doğuran sorunlar da İslam toplumlarının esasen yabancısı olduğu hususlardır (Kabakl1, 1990, s. 200).

Laikliğin Hristiyan düşünce sisteminin bir ürünü olması, çokça anlaşıldığı üzere, onun aslında din ve devlet işlerini ayırmaya yarayan yasal bir düzenleme olmadığını gösterir (Güngör, 1993, s. 326). Nitekim Türkiye'de laiklik uygulaması zaten laikliğin, din işleri ile devlet işlerinin ayrılması anlamına gelmediğinin veya bu şekilde uygulanmasının pek mümkün olamayacağının açık örneğini sergilemektedir:

Laiklik din ve devletin ayrılması demek olursa önce bu ayrılığın yapılması, sonra dinin ve devlet işlerinin sınırlarının bilinmesi ve en mühimi, dinin ne olduğunun iyice bilinmesi gerekir. Evvela Türkiye'de din ve devlet birbirinden ayrılmış değildir; bütün dini gruplar kendi işlerini cemaat 
teşkilatıyla yürüttükleri halde Müslümanların din işleri devletin elindedir, yani Başvekalete bağlı Diyanet İşleri Başkanlığı tarafından yürütülür. Bu hadise hukuki bakımdan siyasi kuvvetin dini kuvveti elinde tutması, yani dinle siyasetin birbirine karıştırılması demektir (Güngör, 1993, s. 327).

Ayrıca din işleri ile devlet işlerinin birbirinden ayrı olması anlamındaki laikliğin, kamu idaresinde görevli kişilerin, görevli oldukları sırada dini kimliklerini yansıtmaması, devlet kurumunun ve diğer sosyal kurumların din kurumundan uzak tutulması ve benzeri şekillerde uygulanması da insan ve toplum doğası gereği tam olarak mümkün değildir (Arslantürk, 2000, s. 331). Zira dindarın, hayatını dini ve din-dışı şeklinde kompartımanlara ayırması, imkânsız denilecek seviyede zordur:

Bir kere ferdin laik olması; tanrı ile bu tür bir politik pazarlığa girmesi mümkün değildir. Fert inanç noktasında tanrıya ya iman eder ya da onu reddeder, ona inanmaz. Kişi dindar olduğu sürece dinin emir ve yasaklarına boyun eğmek, ram olmak zorundadır. Dindardan tanrıyla pazarlık etmesini istemek, onu dinsiz olmaya zorlamaktır. Tanrıya inanan bir kişinin bu inancını davranışlarına yansıtmaması da mümkün değildir. Tanrının kendisinden istediği davranışları yapması zorunluluğu vardır. Hristiyan kiliseye gidecektir, ABD başkanı olsa da İncil'in üzerine el basarak yemin edip göreve başlayacaktır. Müslüman namaz kılacak, oruç tutacak, zekât verecek, içki içmeyecek, faiz almayacaktır. Aksi takdirde tanrının onu cezalandırması ve gazabına uğratması söz konusudur (Arslantürk, 2000, s. 332).

$\mathrm{Bu}$ itibarla Türk-İslam Sentezcilerine göre laiklik temelde farklı dinsel inançların veya felsefi kabullerin birbirine saygı duyması şeklinde anlaşılması gerektiği halde, ne yazık ki Türkiye'de daha ziyade dinden soğutma, dini toplumsal ve hatta bireysel hayattan dışlama aracı olarak kullanılmış ve bu nedenle de toplumun çoğunluğu tarafından benimsenememiştir (Arslantürk, 1998, s. 36). Türkiye'de laikliğe ilişkin bu kavram kargaşası ise bilerek çıkarılmaktadır: "Laiklik, dindarlık, dinsizlik kavramları âdeta kasten ve ayırt edilemeyecek biçimde birbirine karışmıştı"” (Kabakl1, 1990, s. 204). Böylece de "Türkiye'de laiklik mefhumunun istenilen tarafa çekilmesi ve bilhassa siyasi menfaatler, kin ve garezler sebebiyle" gerek yöneticiler gerekse halk tarafından laiklik "din düşmanlığı ve dinsizlik" olarak algılanagelmiştir (Güngör, 2005b, s. 88).

Bununla birlikte Kabaklı (1990, s. 195)'ya göre, devletin farklı dini inançlara saygılı olması anlamında laikliğe, Türk toplumu kendi tarihsel tecrübesi itibariyle yabancı değildir aslında. Çok sayıda din, mezhep ve inanç sisteminin bulunduğu Osmanlı Devleti devrinde laiklik, tam olarak bu anlamıyla, adı konulmamış da olsa vard1. 19. yüzyılda batılı devletlerin tazyikleriyle bu durum bir kısım fermanlarla sadece yazılı hale getirilmişti. Bu sebeple Cumhuriyet'in ilanından sonra anayasadan "Türk devletinin dini din-i İslâm'dır, ibaresini derhal kaldırmak o kadar zarurî” olmadığı gibi, "1937'de TC anayasasına laiklik maddesini geçirmenin zarurî olup olmadığı" da tartışmalıdır.

Son olarak Kurtkan'ın laiklik anlayışı ise oldukça farklıdır. Ona göre laiklik; ahiret ve dünya işlerinin bir arada bulunup birbiri için terk edilmediği ve dengelendiği bir sistem anlamına geldiği gibi; toplumun birlik ve bütünlüğe ulaşması ve böylece kimsenin kimseye zorlamada ve zulümde bulunmaması anlamına da gelmektedir. Aynı biçimde tevhid ve onun en mükemmel anlaşılma biçimi olan -ki bunu mutasavvıflar başarmıştır- vahdet-i vücut, aslında her varlığa ve en başta insana Allah'ın bir "mazharı" olmak payesini vermek suretiyle toplumda açık bir birlik ve bütünlük oluşturan öğretidir. Dolayısıyla ona göre laiklik ile vahdet prensibi esas olarak aynı şeylerdir; vahdetin şuuruna varmış olan kişi ve toplumlar gerçek laikliğe ulaşmıştır (Kurtkan, 1977a, ss. 23-28).

Bu itibarla Kurtkan (1977a, s. 194)'a göre; "laiklik temayülü zaten İslam felsefesinin milletlere örnek gösterdiği kendi öz malıdır ve Hz. Muhammed'in sadece İslam alemine değil, bütün dünyaya bıraktığı en değerli sosyal mirastır." Hatta laiklik, İslam'ın özü ve en temel ilkesi olan tevhid akidesinin koruyucusu konumundaki asli bir İslami değerdir: "Dünyadaki kötülüklerin sadece ahirette cezalandırılmasının, dünya nizâmını temin için kâfi gelemeyeceği fikrini aşılayan değer hükümleri İslâm'in özünü teşkil eden birlik ve bu özün korunması için gerekli olan laiklik değer hükümleridir." (Kurtkan, 1977b, s. 194). 
Kadioğlu, A. S. (2021). Türk-islam sentezcilerinde devlet tasavvuru ve din-devlet ilişkileri.

\section{Sonuç}

Türk-İslam Sentezcileri için devlet, her toplum veya millet için gerekli bir kurum olmakla birlikte Türk milleti için var olabilmenin, gereklilikten de ötede zorunlu şartıdır. Bu çerçevede devletin öncelikli özelliği milli olması olup monarşi, demokrasi gibi yönetim biçimleri temel öneme sahip değildir.

Bununla birlikte Türk-İslam Sentezcilerine göre gerek İslam öncesi Türk devlet geleneğinde gerekse İslami devlet tasavvurunda, demokratik eğilim ve unsurlar çok güçlü biçimde mevcuttur. Bu nedenle Türk ve İslam devlet anlayışı esasen demokratik devlet anlayışıyla örtüşür. Özellikle tiranlık ve diktatörlük gibi baskıcı devlet rejimleri Türk ve İslam devlet tasavvuruna tamamen zit olarak değerlendirilir.

Benzer şekilde Türk-İslam Sentezcileri teokratik devlet anlayışının da çokça iddia edilenin aksine İslami ve Türk devlet geleneğine uygun olmadığını, temel açılardan aykırı olduğunu savunurlar. Bu bağlamda Halifeliğin ise diğer dinlerde görüldüğü gibi dini liderlik anlamında olmadığını, Müslüman halkın dünyevi liderliğini üstlenen kişilere verilen unvan olduğunu kabul ederler.

Türk-İslam Sentezcilerine göre din ve devlet ilişkileri Müslüman-Türk devlet tasavvurunda Batı'da olduğu gibi çatışmalı bir alana tekabül etmez. Zira Batı'dakinin aksine İslam'da inananların hayatı dini ve dünyevi olarak ikiye ayrılmaz ve böylece birbirleriyle rekabete ve çatışmaya girebilme potansiyelini taşıyan dini ve dünyevi alanlar ve güç merkezleri teşekkül edemez. Zaten bu sebeple laiklik de yapısal olarak Müslüman toplumlara ve devletlere esasen yabancıdır. Laikliğin yerine getirdiği iddia edilen işlevleri ise onlara göre İslam'ın özünde mevcut olan ilkeler en güzel bir şekilde ifa etmektedir.

Konumuza ilişkin olarak kendi devrine kadarki felsefi (ve aynı zamanda modern dönemin bakışıyla sosyolojik) birikimi özetleyerek; sosyal ve siyasi bir canlı olan insanın toplum içinde yaşamasının zorunlu olduğunu, bu durumun bir takım toplumsal kuralların varlığını gerektirdiğini, bu gerekliliğin de devleti ortaya çıkardığını söyleyen Farabi (1974, ss. 19,20)'nin bu çıkarımı toplum, hukuk ve devlet arasındaki karşılıklı ilişkinin temelini hala ortaya koymaya devam etmektedir.

Özellikle modern Batı demokrasilerinde, eski kutsallığını kaybederek bürokratik bir aygıta dönüşen devletin diğer ikisi üzerindeki etkililiği önceki çağlara oranla azalmış/azalmakta olsa da Türkiye'de devlet, kutsallığını devam ettirerek, hatta kimi zaman artırarak diğer ikisi üzerinde daha baskın biçimde etkisini gösterebilmektedir. Türk-İslam Sentezcilerinin devlet içindeki etkinliklerinin fikren veya fiilen arttığ zamanların, devletin kutsallığ1 ile toplumsal yap1 ve hukuk üzerindeki etkinliğinin arttığı zamanlara tekabül ettiği görülmektedir. Türkiye ve konumuz açısından daha önemli olansa, dinin/İslam'ın diğer sosyal kurumlar üzerindeki etkisinin de bu artışa koşut bir seyir takip etmesidir.

Bu itibarla günümüz Türkiye'sinde toplumsal, dinsel ve hukuksal yapılardaki değişim ve dönüşümü açıklamak için devlet yönetimini fiilen elinde tutanların devlet tasavvurlarını ve din-devlet ilişkilerine dair görüşlerini yönlendiren düşünsel kökleri bilmek zorunludur. Türkiye'de 15 Temmuz Darbe Girişimi sonrasında oluşan milli konsensüsün siyasi alandaki neticelerinden biri olarak ortaya çıkan Cumhur İttifakı, Türk-İslam Sentezinin özgün bir örneğini teşkil etmektedir. Osmanlı Döneminin son zamanlarında öncelikle beka sorununa çözüm arayışlarıyla tebarüz eden Türk-İslam Sentezi, yüz yılı aşkın süredir devam eden serüveninde pek çok farklı dolayım ve biçimde tebarüz etmiş olup günümüzde yine öncelikle beka sorunu çerçevesinde devleti fiilen yönetir duruma gelmiştir.

\section{Araştırmanın etik yönü}

$\mathrm{Bu}$ araştırmanın etik kurul izni gerektirmeyen araştırmalardan olduğunu beyan ederim.

Makale, 2020 yılı öncesi doktora tez çalışmasında kullanılan verilerden üretilmiş olması sebebiyle etik kurul izni gerektirmeyen çalışmalar arasında yer almaktadır. 
Kayseri Üniversitesi Sosyal Bilimler Dergisí Cilt 3, Sayi: 1, Haziran 2021, 10-23

Kayseri University Journal of Social Sciences. Vol 3, NNo: 1, June 2021, 10-23

\section{9. Çıkar çatışması beyanı}

Çalışmanın sonuçları veya yorumları etkileyebilecek herhangi bir maddi veya diğer asli çıkar çatışması olmadığını beyan ederim.

\section{Katkı Oranı}

Çalışmanın tüm aşamaları yazar tarafından tasarlanmış ve hazırlanmıştır.

\section{KAYNAKÇA}

Arslan, M. (1987). Kutadgu-Bilig'deki toplum ve devlet anlayışı. İstanbul Üniversitesi Edebiyat Fakültesi Yayınları.

Arslantürk, Z. (1998). Kutsalın dönüşü (Yeni toplum arayışları). Ayışı̆̆ı Kitapları.

Arslantürk, Z. \& Amman M. T. (2000). Sosyoloji (Kavramlar-Kurumlar-Süreçler-Teoriler). Kaknüs Yayınları.

Arvasi, S. A. (1979). Türk-İslam Ülküsü 1. Türk Kültür Yayını.

Arvasi, S. A. (1980). Türk-İslam Ülküsü 2. Türk Kültür Yayını.

Arvasi, S. A. (1989). Türk-İslam Ülküsü 3. Burak Yayınevi.

Arvasi, S. A. (1990). Hasbihal 3. Burak Yayınevi.

Arvasi, S. A. (1991). Hasbihal 5. Burak Yayınevi.

Arvasi, S. A. (1996a). Devletin Dini Olur Mu? Burak Yayınevi.

Arvasi, S. A. (1996b). Şüphe ve iman. Burak Yayınevi.

Demirel, D. (2013). Max Weber'in sosyoloji kuram1. Turkish Studies. 8/12 (Fall). 361-369.

Farabi. (1974). Mutluluğu kazanma (Tahsilu's - Sa'ade). (Çev. H. Atay,) içinde, Farabi'nin Üç Eseri. Ankara Üniversitesi İlahiyat Fakültesi Yayınları.

Hegel, G. W. F. (2003). Elements of the philosophy of right. (Çev. H. B. Nisbet,). Cambridge University Press.

Gökalp, Z. (1994). Hürriyetin menbalarına doğru. O. Metehan (Hzl.) içinde, Ziya Gökalp ve din (ss. 9697). Kamer Yayınları.

Gökalp, Z. (2007). Doğru yol - Hakimiyet-i Milliye ve umdelerin tasnif, tahlil ve tefsiri. M. S. Koz (Hzl.) içinde, Kitaplar 1 (ss. 299-317). Yapı Kredi Yayınları.

Gökalp, Z. (2007). Rusya'daki Türkler ne yapmalı? M. S. Koz (Hzl.) içinde, Kitaplar 1 (ss. 25-37). Yap1 Kredi Yayınları.

Göze, A. (2005). Liberal, Marxiste, faşist, nasyonal sosyalist ve sosyal devlet. Beta Basım. 
Kadioğlu, A. S. (2021). Türk-islam sentezcilerinde devlet tasavvuru ve din-devlet iliş̧kilerí.

Güngör, E. (1989). Kültür değişmesi ve milliyetçilik. Ötüken Neşriyat.

Güngör, E. (1993). Sosyal meseleler ve aydınlar. Ötüken Neşriyat.

Güngör, E. (2005a). Tarihte Türkler. Ötüken Neşriyat.

Güngör, E. (2005b). Türkiye'de misyoner faaliyetleri. Ötüken Neşriyat.

Kabaklı, A. (1990). Temellerin duruşması. Türk Edebiyatı Vakfı Yayınları.

Kadıoğlu, A. S. (2020). Türk-İslam Sentezi’nin oluşum ve gelişim süreci. OPUS-Uluslararası Toplum Araştırmaları Dergisi, 16(27), 813-834.

Kadıŏlu, A. S. (2021). Türk-İslam sentezcilerinde hukuk, ahlak ve din ilişkisi. OPUS-Uluslararası Toplum Araştırmaları Dergisi, 17(34), 1549-1569.

Kösoğlu, N. (1997). Devlet -Eski Türkler'de, İslam'da ve Osmanlı'da-. Ötüken Neşriyat.

Kurtkan, A. (1977a). Sosyolojik açıdan tasavvuf ve laiklik. Kutsun Yayınevi.

Kurtkan, A. (1977b). Türk Milletinin manevi değerleri. MEB Devlet Kitapları.

Kurtkan Bilgiseven, A. (1995). Türk-İslam kültüründe fert ve cemiyet ilişkisi ve İslami kavramlar. Filiz Kitabevi.

Marshall, G. (1999). Sosyoloji sözlüğü. (Çev. O. Akınhay \& D. Kömürcü). Bilim ve Sanat Yayınları.

Niyazi, M. (1996). Türk devlet felsefesi. Ötüken Neşriyat.

Türkdoğan, O. (2004). Türk toplum yapısı. Çamlıca Yayınları.

Türk Düşünce Hareketi. (2007). Türk düşüncesi. İrfan Yayımcılık. 